\title{
Eljárás az aeroszol robbanó harcanyagok/harci részek hatásjellemzőinek meghatározására - hazai kutatási eredmények
}

\section{Bevezetés}

1985 és 1990 között, a volt Mechanikai Művek Speciális Rt. (MM Spec. Rt.) kezdeményezésére, az akkori Ipari Minisztérium Hadiipari Főosztálya $\mathrm{K}+\mathrm{F}$ tervet állított össze a nagyenergiájú robbanóanyagok kidolgozására és az ezekkel szerelhető harcanyagok hatásnövelésére irányuló elméleti és (részben) kísérleti kutatásokra, amelyek - elsősorban finanszírozási okok miatt - nem fejeződhettek be.

A tevékenység részeként elemezték és feltárták néhány aeroszol robbanóanyag fizikai, kémiai és műszaki-technikai főbb jellemzőjét, amelyek ismeretében potenciálisan lehetséges egyes közepes és nagy ürméretű romboló tüzérségi lövedékek, rakéta harci részek és romboló bombák hatásnövelése.

Hazánkban, az aeroszol-harceszközök katonai vonatkozású tudományos színvonalú elemzésére első alkalommal 1981-ben [1], majd 1992-ben és 2002-ben [2] került sor.

A szerző napjainkig folytatott kutatásai szerint további $\mathrm{K}+\mathrm{F}$ tevékenység és hadiipari beruházás bázisán valamely prototípus-harcanyag teljes körű statikus minősítő vizsgálata sikeresen megvalósítható Magyarországon. Lövedékek, bombák estén - és megfelelő lőtér (esetleges) hiányában - a további szükséges vizsgálatok nemzetközi együttműködési keretek között hajthatók végre.

\section{ISMERTETÉS, SPECIFIKÁCIÓ}

Az aeroszol robbanóanyagok az aeroszol-harceszközök rendeltetésszerű működése során képződő heterogén

ÖSSZEFOGLALÁS: Hazánkban az 1980-as években született kutatási és kísérleti eredmények nyomán a szerző kidolgozta az aeroszol-harcanyagok hatását elsődlegesen meghatározó aeroszol robbanóanyagok abszolút és (itt) a préselt TNT-re vonatkoztatott relatív hatásfüggvényeit. Bizonyította továbbá hogy ezek explicit kifejtései megegyeznek Borisz Zeldovics robbanóanyagok detonációs folyamataira kidolgozott hidrodinamikai elméletének vonatkozó kifejezéseivel és megállapításaival. Mindezek alkalmazásával vázolta az aeroszol detonáció t(h)ermobar hatásait, továbbá fénykép-dokumentációkkal szemléltette a hazai főbb kísérleti vizsgálatokat.

KULCSSZAVAK: Aeroszol, thermobar robbanóanyagok, robbanó harcanyagok, aeroszol robbanóanyagok hatásai diszperz rendszerek, amelyek levegőből, éghető anyagok szoljaiból, gázaiból és gőzeiből állnak, és amelyek rendszer szinten képesek - a (gyors) égési fázis kihagyásával - folytonos, stabil, és a rendszerre jellemző maximális sebességű detonációra, iniciáló impulzus hatására [15]. A diszperziók szemcsemérete $5 \cdot 10^{-7} \cdot 10^{-9} \mathrm{~m}$.

Éghető anyagként különböző halmazállapotban jelenlévő - általában önmagukban nem robbanó - anyagokat [16] alkalmaznak, amelyeknek a levegő együttes oxigén és nitrogén komponenseivel alkotott alsó és felső robbanási, valamint detonációs határkoncentrációi alacsonyak (max. $10 \%)$ és közel azonosak [16, 17], továbbá iniciálásuk kizárólag növelt energiatartalmú és detonációs impulzusú detonátorokkal lehetséges [2].

A követelményeknek megfelelő leggyakrabban alkalmazott anyagok: flegmatizált és inhibitált; szilárd/folyékony halmazállapotú

- fémorganikus (Li, Mg, Al, B, Fe) vegyületek, továbbá

- szerves oxidok (etilén, propilén) [6],

- szén, fémporok (Al, Mg, Am ötvözet, [17]).

Robbanóanyag-diszperziók (esetleges) alkalmazása nem járna plusz előnnyel a fenti anyagokhoz képest, mivel a fentiek szerinti méreteik nagyságrendekkel kisebbek a stabil detonációjukhoz szükséges kritikus/határméreteknél. Vagyis önmagukban detonációra képtelenek, így az ennek megfelelő sebességű átalakulásuk kizárólag a diszperziósfázis-állapotukban következhet be [2].

A harceszközök harci részei a heterogén diszperziók képzésére (előállítására) optimális méretű detonációs (lég-) térben történő szétoszlatására és az aeroszol robbanó-

ABSTRACT: Based on the research and experimental results gained in Hungary in the 1980s, the author elaborated absolute and relative action integrals of the aerosol explosive materials which primarily determine the effect of the aerosol warfare agents; the relative one is related here to the pressed TNT. He also proved that the explicit explanations of them are consistent with the relevant expressions and findings of Boris Zeldovich's hydrodynamic theory of explosive detonation processes. Using all these, he outlined thermobaric effect of the aerosol detonation and illustrated the main Hungarian experimental studies by the use of photographic documents.

KEY WORDS: Aerosol explosives, thermobaric explosives, explosive war agents, effects of aerosol explosives

\footnotetext{
Hadtudomány (haditechnika) kandidátusa, NKE Hadtudományi Doktori Iskola (National University of Public Service Doctoral School) ORCID:0000-0002-3411-831X
} 
anyag iniciálására alkalmas aktív töltetekből $[16,18,19]$ állnak. A diszpergálást és az elkeverést minden esetben robbantással valósítják meg.

Az aktív töltet lökőtöltetből és egy vagy több nagy detonáció-sebességű (D: min. 8-9000 ms) és nagy detonációs impulzus generálására alkalmas (fenti iniciálási funkciót ellátó) detonátorból áll. A lökőtöltet anyaga alacsony detonációsebességú (D: max. 5-800 ms) brizáns/tolóhatású, alacsony detonációs hullámfront hőmérsékletű (T: max. $500 \mathrm{~K})$ folyékony és/vagy szilárd halmazállapotú robbanóanyag.

A szol az aktív töltet mechanikus aprításának - gyakorlatilag teljes egészében - az inhibítor/flegmatizátor párolgásának (szublimációjának) következményeként képződik.

Az aeroszol-harceszközök az aeroszol robbanóanyagok potenciális energiáit hasznosítják [20]. Rendeltetésük a különböző szélességben és mélységben elhelyezkedő élőerő-csoportosítások megsemmisítése, illetve harcképtelenné tétele [20] és (elsősorban) mesterséges objektumok (építmények, épületek) rombolása [21].

A harceszközök alkalmazásának célszerű formája tömeges méretű, egyidejű bevetésük [20, 22] a fegyvernemek első, majd (szükség szerint) következő csapásainak részeként.

\section{AZ AEROSZOL HARCI RÉSZEK, HARCANYAGOK ÉS ROBBANÓANYAGOK HATÁSJELLEMZŐI}

A szerző kutatásai szerint bármely harcanyag valamennyi hatásjellemző mérőszáma kifejezhető a beszerelt brizáns robbanóanyag-főtöltet detonációs hullámfrontját szabatosan jellemző gázdinamikai függvények összességével. A harcanyag valamely domináns hatásának megfelelő mérőszám leírható ezek közül egyetlen, a domináns hatást jellemző függvénnyel. [23]. A függvényeket a hivatkozott saját publikációkban bemutatta a szerző, azok a rendelkezésre álló szakirodalmakban nem találhatók meg.

A hg-index jelü - ezen belül a- (index) azonosítóval specifikált harcanyag $X_{h g, a}$ hatásfüggvényei - amelyek bármely harcanyagra vonatkozhatnak - az alábbiak:

$$
X_{h g, a}=f_{X_{h g, a}}\left(Y_{k s}, Y_{c e ́ l}, Y_{r g}\right)
$$

ahol, $Y_{k s}, Y_{c e ́ l}, Y_{r g}$ függvények, amelyek sorrendben a harcanyag konstrukciójára (ks), a leküzdendő célra (cél) és a főtöltet robbanóanyagára $(r g)$ vonatkoznak.

A továbbiakban a $h g=A E$-index jelű aeroszol-harcanyagok rendeltetésszerű működése során képződő, $a=$ ae-index jelű aeroszol robbanóanyagok $X_{h g=A E, a=a e}$ hatásjellemzőinek kifejtésére kerül sor. Az ide vonatkozó általános összefüggés, az (1) egyenlet módosított változata, amelyben $Y_{k s s}, Y_{\text {cél }}$ függvények hiányoznak.

$X_{A E, a e^{-t}}$ szabatosan jellemezhető a fötöltet detonációs hullámfrontjához rendelhető, max. 2 elemi gázdinamikai függvénnyel, amelyek közül sebességjellemzők a $D_{r g} \equiv Y_{r g, D}$ és $v_{r g} \equiv Y_{r g, v}$, ahol $D_{r g}$ a robbanóanyag detonációsebessége, $v_{r g}$ a robbanóanyag detonációs végtermékének áramlási sebességfüggvénye a hullámfront normálisának irányával egyezően. Továbbá 3 gázállapotjelző függvénnyel, amelyek $(\rho, T, \rho)_{r g} \equiv Y_{r g,(p, T, \rho)}$, ahol $T$ a hőmérséklet, $\rho$ a sürüség, illetve a következő származtatott hatásjellemző függvényekkel: fajlagos impulzus, detonációs időtartam, összegzett erőlökés, detonációs tartomány maximális térfogat, amelyek $I_{r g} \equiv Y_{r g, l}, \Delta t_{r g} \equiv Y_{r g, \Delta t}, \sum I_{A} \equiv A \Delta t_{r g} \equiv Y_{r g, \Sigma}, V_{r g, g, m a x} \equiv Y_{r g, y}$, ahol $A$ a detonációs hullámfront felülete, $F$, az ezen felületre ható erő. Vagyis,

$$
\left[X_{A E, a e}\right]_{i=(D, v, p, T, \rho)_{r g}}=\left(Y_{r g, D}, Y_{r g, v}, Y_{r g, p}, Y_{r g, T}, Y_{r g, \rho}, Y_{r g, \Delta t}, Y_{r g, \Sigma}, Y_{r g, V}\right)
$$

$X_{A E, a e}$ analitikus formái felírhatók az alábbiak szerint. (Lásd a [23] publikációkat, amelyekben bizonyítást nyert, hogy ezek mindegyike a valamely $Y_{r g, i}, n$-ed rendű algebrai kifejezése.)

$$
\left[X_{A E, a e}\right]_{i}=P_{i}+Q_{i} \Delta U_{r g / g, A}^{m_{\alpha \prime \beta}}
$$

ahol,

$P_{\text {: }}$ dimenzió nélküli állandó.

$Q_{i}:$ Függvényértékek, amelyek dimenziói és mérőszámai is, a valamely $i, \ldots, j$ hullámfront-jellemzőként különbözőek, de ugyanazon jellemzők esetén, számértékeik közel egyezőek.

$\Delta U_{r g / g, A}$ : A robbanóanyag és a g-index jelű detonációs végtermék közötti fajlagos (tömegegységre vonatkoztatott) belsőenergia-változás függvénye a detonációs hullámfront $A$-index jelű felületén.

$m_{\alpha}$ és $m_{\beta}$ : Természetes számok - valamennyi $i$-re - a következők szerint:

$$
0<m_{\alpha} \leq 1 \text { és } 0<m_{\beta} \leq 2
$$

A: A detonációs hullámfront felülete. Továbbá,

$$
P_{i}<<Q_{i} \Delta U_{r g / g, A}^{m_{\alpha / \beta}} \text {, ezért közelítéssel } P_{i} \text { elhanyagolható. }
$$


A fenti (3-5) összefüggések - a szerző hivatkozott szakirodalomban részletezett módszere szerinti - következő általános megoldásai függvények, amelyek megegyeznek a Ja. B. Zeldovics által megalkotott és a robbanóanyagok detonációs hullámfrontján értelmezhető gázdinamikai egyenletekkel [12] [24].

$$
D_{r g}=\left[2\left(n^{2}-1\right) \Delta U_{r g / g, A}\right]^{1 / 2}
$$

ahol, $n, g$ : a gázfázisú detonációs végtermék politrop- (közelítő számításoknál) izentróp kitevője, átlagos molekulatömege.

A hatásjellemzők relatív (összehasonlító) függvényeinek megállapításához, a vizsgálatok részeként egy tűzben indítható, $1,55 \mathrm{gcm}^{-3}$ sürűségű homogén TNT préstestből álló, No. 8. számú gyutaccsal indítható, burkolat nélküli robbanóanyag-tölteteket használtak fel. A vizsgálati eredményeknek megfelelően, az (1-6) összefüggések felhasználásával meghatározott fenti hatásfüggvények, a következők,

$$
\begin{gathered}
\left(\frac{D_{r g}}{D_{r g, 0}}, \frac{v_{r g}}{v_{r g, 0}}, \frac{T_{r g}}{T_{r g, 0}}\right)=\left(\frac{\Delta U_{r g / g, A}}{\Delta U_{(r g / g, A) 0}}\right)^{1 / 2} \\
\frac{p_{r g}}{\rho_{r g, 0}}=\frac{\rho_{r g}}{\rho_{r g, 0}} \frac{\Delta U_{r g / g, A}}{\Delta U_{(r g / g, A) 0}} \\
\frac{\rho_{r g, g}}{\rho_{r g, g, 0}}=\frac{\rho_{r g, g, k e z d}}{\rho_{r g, 0}}
\end{gathered}
$$

Továbbá, a származtatott függvények

$$
\begin{gathered}
\frac{\Delta t_{r g}}{\Delta t_{r g, 0}}=(4 \pi)^{\frac{2}{3}} \frac{n}{(n+1)^{\frac{1}{3}}}\left(\frac{m_{r g}}{m_{r g, 0}} \frac{\rho_{0}}{\rho_{r g, k e z d .}}\right)^{\frac{1}{3}}\left(\frac{\Delta U_{(r g / g, A) 0}}{\Delta U_{r g / g, A}}\right)^{\frac{1}{2}} \\
\frac{\sum I_{A}}{\sum I_{(r g, 0) A}}=\frac{A \Delta t_{r g}}{A_{0} \Delta t_{r g, 0}}=\frac{m_{r g} A \Delta t_{r g}}{\left(m_{r g} A_{0} \Delta t_{r g}\right)_{0}}\left(\frac{\Delta U_{r g / g, A}}{\Delta U_{(r g / g, A)_{0}}}\right)^{\frac{1}{2}}
\end{gathered}
$$

\section{KöVETKEZTETÉSEK}

Az előzőekben ismertetett heterogén diszperz rendszerek mindegyikénél $\Delta U_{r g / g, A}>\Delta U_{(r g / g, A)_{0}}$ és $m_{r g} \geq m_{r g, 0}$, ezért a detonációsebesség, a detonációs végtermékek áramlási sebessége, az összegzett erőlökés és a hőmérséklet relatív mérőszámai, 1-1,5 nagyságrend szorzótényezők szerint nagyobbak a fenti TNT-referencia töltetekénél.

Az aeroszol-főtöltetek és a referencia-töltetek, nyomás és sűrűség hatásjellemzőinek relatív mérőszámai a fentinél általában kisebbek, max. 1 érték szerintiek. A hatásjellemzők vonatkozásaiban az aeroszol-harcanyagok jelentősége abban nyilvánul meg, hogy épületek, építmények rombolására irányuló rendeltetésszerű felhasználásaik esetén $V_{r g} / g$,max mérőszámai beállíthatók a rombolandó objektumok (saját) rezonancia-frekvenciáinak tartományaiba, és az ezen időtartamok során az összegzett erőlökéseik - tehát az ezen származtatott hatásjellemzőik mérőszámai - 2-3 nagyságrend szorzótényező szerint haladhatják meg a referenciaértékeket [19, 25].

Az aeroszol-harcanyagok és robbanóanyagok további haditechnikai jellemzője azok thermobar hatása, amely egyedülálló a hagyományos harcanyagok között [26, 27].

Az aeroszol robbanóanyagok detonációinak következményeként, a megnövekedő hőmérséklet mellett, min. a $V_{r g}$ g,max térfogatban - gyakorlatilag - az oxigén és (az aeroszol töltet konstrukciójától függően) a nitrogén összes mennyisége elhasználódik a kémiai reakciók során és légzésre - általában - alkalmatlan oxigénhiányos állapot következik be, min. a $\Delta t_{r g}$ időtartam során. Ennek következménye, a néhányszor $V_{r g / g \text {,max }}$ térfogatban lévő élőerők nagy számának harcképtelenné válása, esetleg részleges megsemmisülése [28, 29].

Megjegyzés: A hatékonysági jellemzők kifejthetősége. A fenti harci részek és harcanyagok hatékonyságjellemzőit jelen publikációban nem elemeztük. Ugyanis a jellemzők szabatos kifejtéséhez szükségesek a vázolt hatásjellemzőkön túlmutató egyéb információk, ezeken belül elsősorban a valamely helyi háború során, a valamely aeroszol robbanóanyag/ harcanyag rendeltetésszerű alkalmazására vonatkozó logisztikai feltételek ismeretei nem állnak rendelkezésre. Mindezek következményeként, a fenti jellemzők explicit formái nem állíthatók elő.

\section{Szemléltetés}

Az alábbi filmkockák szemléltetik a bevezetésben hivatkozott $K+F$-tevékenység részét képező 15 kg mennyiségű, szubmikroszkópos - mikroszkópos mérettartományú Al/Mg/C:20/20/60\% összetételű aeroszol-főtöltet detonációs folyamatát. Az iniciálás kezdeti időpontja, a filmkockák közötti időtartam-különbség 1/100 s, az egyes felvételek exponálási időtartama: 1/1000 s.

A kísérleti robbantások filmfelvételeinek elemzési eredményei elégséges alapul szolgáltak a fenti elméleti megállapítások igazolására. 


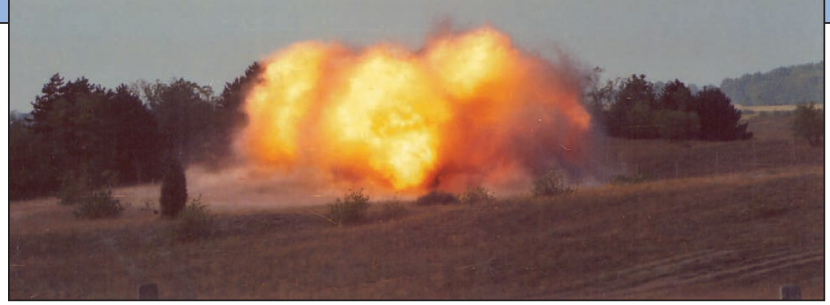

1. ábra. $t_{1}: t_{0}+0,01 \mathrm{~s} \Delta t_{\text {exp }}: 0,001 \mathrm{sec}$. A detonációs térfogat max. átméróje: $16 \mathrm{~m}$, magassága: $7 \mathrm{~m}$

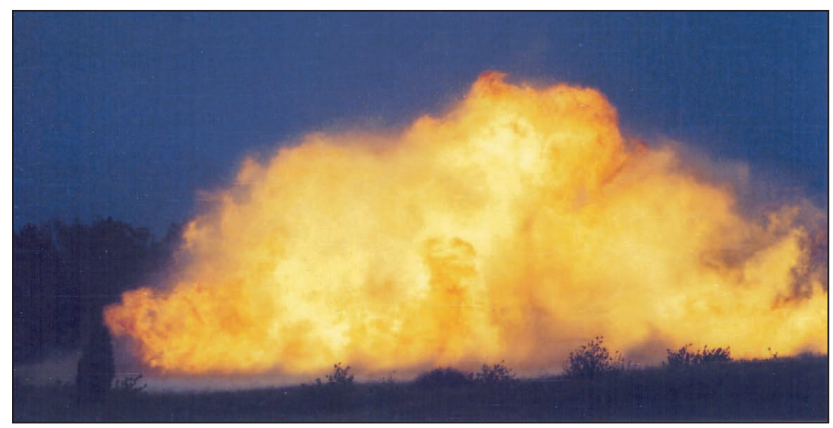

3. ábra. $t_{3}: t_{2}+0,01 s \Delta t_{\text {exp }}: 0,001 \mathrm{sec}$. A detonációs térfogat max. átmérốje: $25 \mathrm{~m}$, magassága: $15 \mathrm{~m}$

\section{FELHASZNÁLT IRODALOM}

[1] Ungvár Gyula. „Az 1970-es évek tüzérségi lőszerfejlesztési eredményei a nyugati államokban." Haditechnikai Szemle 15, 4. sz (1981): pp. 12-17.;

[2] Molnár László. Robbanásfizika. Kézirat. Miskolci Egyetem, 1987.;

[3] Molnár László. Implóziós robbantás. Kandidátusi értekezés. Budapest: Zrínyi Miklós Nemzetvédelmi Egyetem, 1992.;

[4] Lukács László. Az idegen hadseregek átjárónyitó eszközei 1-3. Müszaki Katonai Közlöny 3. évf., 1., 2., 3. sz. (1993);

[5] Lukács László. „A föld akna problémája és a megoldás lehetőségei, különös tekintettel a magyar honvédség közreműködésének javasolható irányaira 1-3." Müszaki Katonai Közlöny 7. évf., 1., 2. és 3-4. szám (1997);

[6] Molnár László. „Aeroszol- robbanó harceszközök.” Bólyai Szemle 11. évf., Különszám III. (2002): pp. 159-168.;

[7] Molnár László. „Aeroszol robbanóanyagok katonai és polgári célú hasznosításának néhány vonatkozása." Fúrás- Robbantástechnikai Nemzetközi Konferencia, 2008. pp. 151-157.;

[8] Molnár László. Néhány perspektivikus lehetőség elemzése hagyományos robbanó harcanyagok / harcirészek hatékonyságának növelésére. ZMNE Hadtudományi Doktori Iskola. Tantárgy, 2011.;

[9] Ласло Др. Молнар. „Метод расчета при определении действия и эффективности традиционных взрывчатых боевых веществ/боевых частей." ВОПРОСЫ ОБОРОННОЙ ТЕХНИКИ, Выпуск 7-8, (2013): рр. 53-58.;

[10] Ласло Др. Молнар. „Имплозивная детонация. Моделирование и возможный способ исчисления характеристик фронта детонационной волны." ВОПРОСЫ ОБОРОННОЙ ТЕХНИКИ, Выпуск 1 - 2, (2014) рр. 33-38.;

[11] Molnár László. Robbanóanyagok, robbanó harcanyagok alkalmazása, hatása, hatékonysága. ZMNE Hadtudományi Doktori Iskola. Tantárgy, 2015;

[12] Molnár László. Repülögépfedélzeti fegyverek részét képező bombák, rakéták harcirész - hatásainak, -hatékonyságának fejlődése. 13. Fúrás-

Robbantástechnika Nemzetközi Konferencia, 2016;

[13] Cifka Miklós. Az NH90 korszerű közepes szállító helikopter. Haditechnika 45. évf., 5. sz. (2011). pp. 24-27.;
2. ábra. $t_{2}: t_{1}+0,01 s \Delta t_{\text {exp }}: 0,001 \mathrm{sec}$. A detonációs térfogat max. átmérốje: $28 \mathrm{~m}$, magassága: $8 \mathrm{~m}$

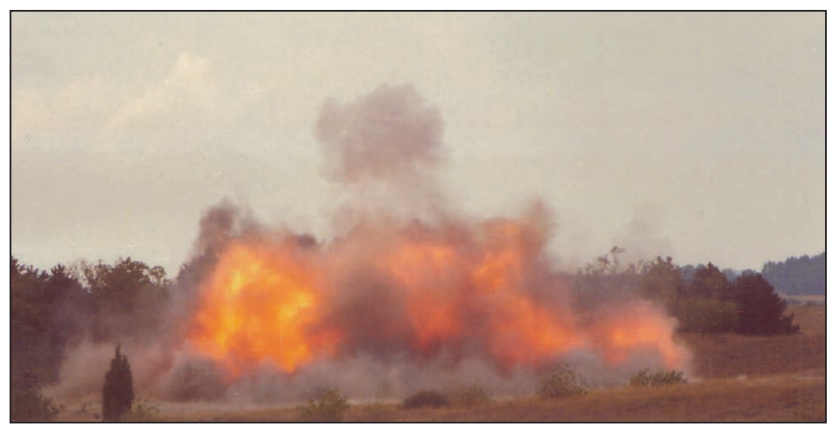

4. ábra. $t_{4}: t_{3}+0,01 s \Delta t_{\text {exp }}: 0,001 \mathrm{sec}$. A detonációs térfogat max. átmérốje: $15 \mathrm{~m}$, magassága: $5 \mathrm{~m}$

[14] Szilvássy László. Légibombák - termobarikus (aeroszol) bomba. Repüléstudományi Közlemények 30. évf., 3. sz (2018. november): pp. 7-14.;

[15] Kulczynszky, S.: „Amunicija poliwowopowi etrzna.” Wosjkowy Przeglad Techniczny, 12. évf. /9. sz. 436. p.;

[16] Simits, D. - Popovits, M. - Sirovatka, R. - Andelits, U.: „Influence of Cast Composite Thermobaric Explosive Compositions. Scientific Technical Rev., 2013 Vol. No. 2, pp. 63-69.;

[17] Sikorska, A.: Materialy wybuchowe o duzej energii, Wosjkowy Przeglad Techniczny 12. évf., 3. sz (1980): 102-103.p.;

[18] Wildegger - Gaissmaier, A.: „Aspects of Thermobaric Weaponry" Military Technology, Vol. 28, No.6. (2004): pp.125-130.;

[19] Lavoine, L.: „Fuel Air Explosives, Weapons and Effects" Military Technology, Vol. 13., No. 09. (1989);

[20] Damó László (szerk.): Katonai Lexikon, Budapest: Zrínyi Katonai Könyvkiadó, 1985.;

[21] Kim, C. K., Hwang, J. S., Im, K. S.: Numerical simulation of afterburning of thermobaric explosive products in air. 23-rd International Symposium on Ballistics, Spain, 2007.;

[22] Kocsis Bernát. A hadtudomány általános elmélete és a hadmüvészet, Budapest, Zrínyi Kiadó, 1987.;

[23] Molnár László. „Repeszlövedékek/harcirészek hatékonysága és a repesztöltetek fajlagos energiatartalmai közötti összefüggések, I-IV. rész," Müszaki Katonai Közlöny 19. évf., 1-4 sz., (2009).;

[24] Zeldovics, Ja. B.: Teorija udarnüh voln $i$ vvedjenie $v$ gazodinamiku, Moszkva, Izd. AN SZSZSZR, 1946.;

[25] Barcz, K., Trcinsky, W. A.: „Thermobaric and enhanced blast explosives" Biuletyn Wojskowej Akademii Technicznej. Vol. 59, nr. 3. (2010): pp. 7-39.;

[27] Szilvássy L.: Légibombák - termobarikus (aeroszol) bomba. Repüléstudományi Közlemények, 2018 / 3. pp. 7-14.;

[28] Xing, Xiao Ling, Sheng Xiang Zhao, Zhen Yu Wang, and Guang Tao Ge.: "Discussions on Thermobaric Explosives (TBXs)." Propellants, Explosives, Pyrotechnics 39, no. 1 (December 2, 2013): 14-17. https://doi.org/10.1002/prep.201300003;

[29] Hahma, A., Palovuori, K., Solomon, Y.: TNT Equivalency of Thermobaric Exploives. 36th International Pyrotechnics Society, Germany, 2005. 